\title{
Crystal structure of vanadinite: Refinement of anisotropic displacement parameters
}

\section{Krystalová struktura vanadinitu: zpřesnění anizotropních teplotních parametrů}

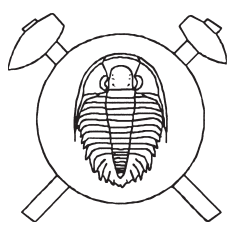

(2 figs, 5 tabs)

\author{
FRANTIŠEK LAUFEK ${ }^{1}$ - ROMAN SKÁLA² - JAKUB HALODA ${ }^{1}$ - IVANA CÍSAŘOVÁ ${ }^{3}$ \\ ' Czech Geological Survey, Geologická 6, Praha 5, CZ-152 00 Czech Republic \\ ${ }^{2}$ Institute of Geology, Academy of Sciences of the Czech Republic, Rozvojová 135, Praha 6, CZ-165 02 Czech Republic \\ ${ }^{3}$ Faculty of Science, Charles University, Hlavova 8, Praha 2, CZ-128 43 Czech Republic
}

\begin{abstract}
The structure of vanadinite, $\mathrm{Pb}_{5}\left(\mathrm{VO}_{4}\right)_{3} \mathrm{Cl}$, from Mibladén, Morocco, was refined from single-crystal X-ray data. The full anisotropic structural refinement was carried out in the hexagonal space group $P 6_{3} / m$, unit cell parameters $a=10.2990(2), c=7.3080(1) \AA$, $V=671.30(2) \AA^{3}, Z=2$, with an $R$ factor of 0.0197 . The full anisotropic crystal structure refinement results in smaller departures of bond valence sums for cations from the ideal value than the isotropic one.
\end{abstract}

Key words: vanadinite; crystal structure; anisotropic displacement parameter; single-crystal X-ray refinement

\section{Introduction}

Vanadinite, $\mathrm{Pb}_{5}\left(\mathrm{VO}_{4}\right)_{3} \mathrm{Cl}$, is an end member in the ternary system pyromorphite-vanadinite-mimetite. It belongs to the apatite-group (Mandarino - Back 2004). By analogy with the other apatite-group minerals that crystallize in space group $P 6_{3} / m$, vanadinite was presumed to be hexagonal (Hendricks et al. 1932). Thirty years after the first description of the vanadinite structure, Trotter Barnes (1958) studied the three-dimensional atomic arrangement in the phase. They refined the vanadinite structure to $R=12 \%$ using visual estimates of intensities from precession photographs. More recently, single crystal $\mathrm{X}$-ray refinement of vanadinite was reported (Dai Hughes 1989). In their refinement, the displacement parameters for cations were refined as anisotropic whereas oxygen atoms were refined as isotropic only. Despite the abundance of museum-quality specimens, full anisotropic structural refinement of vanadinite is still lacking. Partly to blame are some serious experimental difficulties: the X-ray scattering is dominated by highly-absorbing lead atoms, and vanadium interaction with neutrons is negligible. The aim of this work was to perform full anisotropic structure refinement and evaluate the effects of anisotropic displacement parameters refinement on the crystal structure of vanadinite.

\section{Locality and properties}

Since 1979, Morocco has been an important source of superb large vanadinite crystals or aggregates thereof (White 1984). One of the major vanadinite localities in Morocco is carbonate-hosted stratabound lead deposit in Mibladén, upper-Moulouya district ( $32^{\circ} 46^{\prime} \mathrm{N}, 4^{\circ} 38^{\prime} \mathrm{W}$; Fig. 1). This locality also provided the sample studied. The sample that contains vanadinite was purchased at a mineral fair in 2004 from a Czech mineral dealer. The sample was labelled "vanadinite" from Mibladén, Morocco.
Mineralization at Mibladén is comparable to other carbonate-hosted lead-zinc deposits, sharing numerous characteristics with the Mississippi Valley type deposits (Jébrak et al. 1998). The lead ore at Mibladén is restricted to the Mesozoic units near the present outcrop limit of the formation, where the thickness of the sediments is minimal. Most of the lead ore is hosted by Domerian (=Midle Lias) dolomitic to carbonaceous formations (Felenc - Lenoble 1965).

At Mibladén, vanadinite occurs as an alteration product of galena in close association with barite, cerussite and anglesite. The crystals are characterized by their remarkable size (commonly up to $1 \mathrm{~cm}$ in length), a deep red colour and adamantine lustre. The crystals are short hexagonal prisms terminated by a basal pinacoid. This makes them different from the barrel-shaped crystals common to the apatite group minerals.

\section{Crystallographic data and chemical composition}

Data for crystal structure refinement were acquired using 4-circle single-crystal diffractometer Nonius KappaCCD at the Centre of Molecular Structures at the Faculty of Science, Charles University, Prague. The program COLLECT (Nonius 1997-2000), was used for data collection. Unit-cell refinement and data reduction was carried with program HKL-SCALEPACK (Otwinovski Minor 1997). After correction the data for absorption (Spek 2001), the structure was solved applying Sir92 (Altomare et al. 1994) and subsequent refinement was carried out with SHELX97 program (Sheldrick 1997). The programs of the SHELX97 suite were operated through WinGX graphical interface (Farrugia 1999). Two refinements of the structure were carried out. In the first, we refined all the atoms anisotropically. In the second one, only heavy atoms were refined anisotropically, whereas oxygen displacement parameters isotropically. Other refined parameters were the same in both refine- 


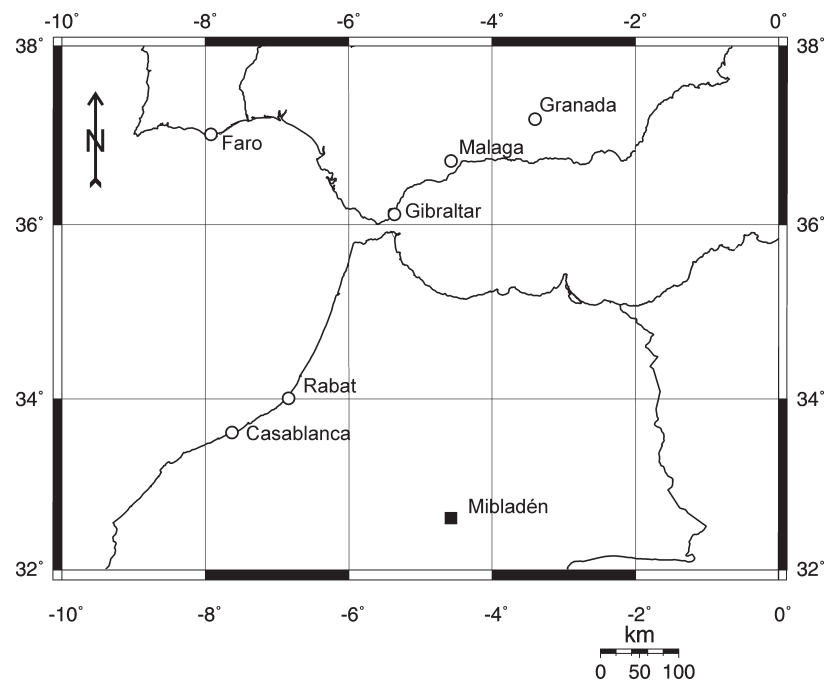

Fig. 1 Sketch map showing the geographic location of the Mibladén locality.

ments and included scale factor, positional parameters, and an isotropic extinction factor. Neutral atomic scattering factors, including terms for anomalous dispersion, were used in the refinement. The graphical representation of the structure was prepared with DIAMOND (Crystal Impact 2004) program and is shown in Fig. 2. Experimental details and crystal data are listed in Table 1, atomic positions and anisotropic temperature parameters are listed in Tables 2 and 3, respectively.

The quantitative chemical composition of the examined crystal was measured with a scanning electron microprobe CamScan 4 with a wave-dispersive analyser
Microspec WDX-3PC. The following conditions were used: operating voltage $15 \mathrm{kV}$, beam current $16 \mathrm{nA}$, with Phi $($ rho $\times Z$ ) correction procedure and the standards vanadium $(\mathrm{V})$ and lead $(\mathrm{Pb})$. Results of six analyses, when averaged and recalculated on the basis of twelve oxygen atoms, yielded the following chemical formula: $\mathrm{Pb}_{5.00} \mathrm{~V}_{2.99} \mathrm{O}_{12.00} \mathrm{Cl}_{1.00}$; isomorphous elements like $\mathrm{P}$ and $\mathrm{As}$ were below the detection limits.

Infrared spectroscopic analysis, performed with FTIR spectrometer Magna 760 Nicolet using KBr pellet within the $400-4000 \mathrm{~cm}^{-1}$ range, rules out the presence of $\mathrm{OH}-$ groups.

\section{Interpretation of results}

The full anisotropic refinement of the vanadinite structure is in agreement with the atomic arrangement determined for this mineral by Dai - Hughes (1989). Consequently, the reader is referred to the papers of TrotterBarnes (1958) and Dai - Hughes (1989) for a thorough description of the vanadinite structure.

In order to show the effect of refinement of anisotropic displacement parameters, we calculated effective coordination numbers (ECoN) (Hoppe 1979) for cations as $\mathrm{Pb}$ and $\mathrm{V}$ and bond valence sums. The effective coordination numbers were calculated by means of the program of Rieder (1993), the bond valence calculations were carried out according to Brese - O'Keeffe (1991) using the program Ivton (Balić-Žunić - Vicković 1996). Comparison between the calculated bond valence sums (BVS) and effective coordination numbers (ECoN) (Hoppe

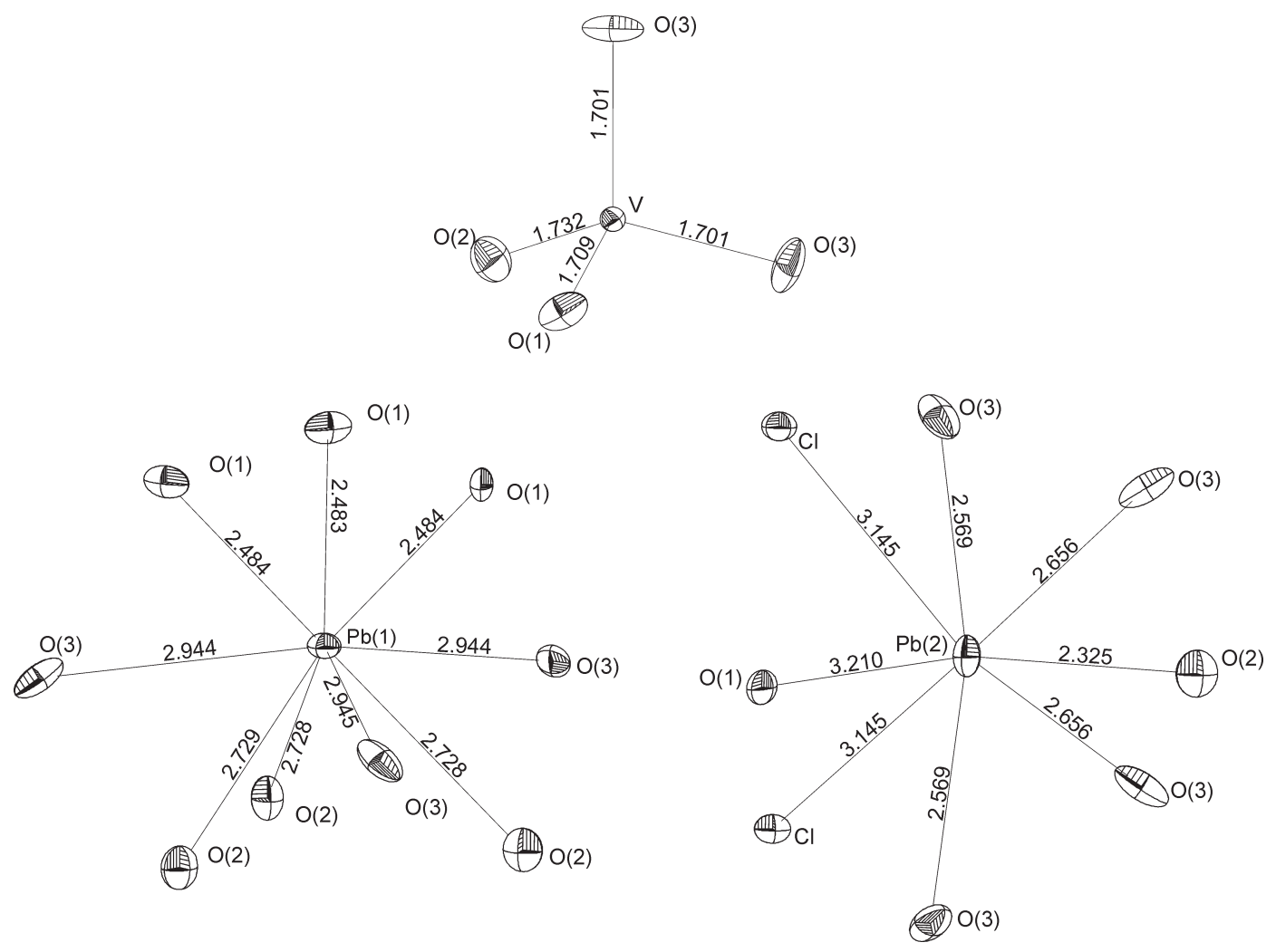

Fig. 2 Perspective diagrams for $\mathrm{Pb} 1, \mathrm{~Pb} 2$ and $\mathrm{V}$ polyhedra in vanadinite. For each polyhedron, the $c$ axis is vertical and $\boldsymbol{a}$ axis is approximately perpendicular to the plane of the drawing. 
Table 1 Crystal data of vanadinite and structure refinement details.

\begin{tabular}{|c|c|}
\hline Space group & $\mathrm{Pb}_{3} / m($ No. 176$)$ \\
\hline Unit cell dimensions $(\AA)$ & $a=10.2990(2), c=7.3080(1)$ \\
\hline Volume $\left(\AA^{3}\right)$ & $671.30(2)$ \\
\hline Z, Calculated density (g.cm ${ }^{-3}$ ) & $2,7.006$ \\
\hline Absorption coefficient $\left(\mathrm{mm}^{-1}\right)$ & 64.7 \\
\hline$F(000)$ & 1184 \\
\hline Absorption correction procedure & empirical \\
\hline Wavelength $(\AA)$ & 0.71073 \\
\hline Crystal size (mm) & $0.19 \times 0.16 \times 0.07$ \\
\hline$\Theta$ range for data collection $\left(^{\circ}\right)$ & 3.60 to 30.02 \\
\hline Index ranges & $-14 \leq h \leq 14,-14 \leq k \leq 14,-10 \leq l \leq 10$ \\
\hline Reflection collected & 23247 \\
\hline Independent reflections & 706 \\
\hline Refinement method & Full-matrix least squares on $F^{2}$ \\
\hline Data/restrains/parameters & $706 / 0 / 40$ \\
\hline Goodness-of-fit on $F^{2}$ & 1.225 \\
\hline Final $R$ indices $[\mathrm{I}>2 \sigma]$ & $R=0.0197, w R=0.0458$ \\
\hline$R$ indices (all data) & $R=0.0209, w R=0.0470$ \\
\hline Weighting scheme & $w^{-1}=\left[\sigma^{2}\left(F_{o}^{2}\right)+(a P)^{2}+b P\right)$ \\
\hline & where $P$ is $\left[F_{o}^{2}+2 F_{c}\right] / 3$ \\
\hline \multicolumn{2}{|c|}{ Goodness-of-fit $=\left\{\Sigma\left[w\left(F_{o}^{2}-F_{c}^{2}\right)\right] /(n-p)\right\}^{1 / 2}$} \\
\hline \multicolumn{2}{|c|}{$R=\Sigma|| F_{o}|-| F_{c}|| /\left|F_{o}\right|$} \\
\hline \multicolumn{2}{|c|}{$w R=\left\{\Sigma\left[w\left(F_{o}^{2}-F_{c}^{2}\right)^{2} / \Sigma\left[w\left(F_{o}^{2}\right)^{2}\right]\right\}^{1 / 2}\right.$} \\
\hline
\end{tabular}

1979) derived from the data of Dai - Hughes (1989) and those from this study is shown in Table 4. The full anisotropic refinement results in smaller departures of BVS from the ideal value.

Bond lengths resulting from our refinement display slight differences when compared to those of Dai - Hughes (1989) (Table 5). These discrepancies, however, might theoretically be attributed to different size of the unit cells. To assess the differences observed and to quantify the amplitude of deviations in bond lengths and angles, respectively, we applied an approach of the so-called distortion parameters. Such distortion indicators as bond angle variance and bond length distortion are commonly used to characterize the departure of an irregular polyhedron from ideal regular geometry. Probably the most common distortion parameter that is suitable to characterize the distortion of a polyhedron is the bond angle variance, $\sigma^{2}$, which was introduced by Robinson and co-workers (1971) $\sigma^{2}$ as $=\sum_{i=1}^{n}\left(\theta_{i}-\theta_{0}\right)^{2} /(n-1)$ where $\theta_{0}$ is the ideal bond angle for a regular polyhedron (e.g. $90^{\circ}$ for an octahedron, $109.47^{\circ}$ for a tetrahedron), $n$ is the number of bond angles in the coordination polyhedron, and $\theta_{i}$ are individual bond angles. The bond length distortion
Table 2 Atomic coordinates and equivalent isotropic displacement parameters of vanadinite from Mibladén, Morocco.

\begin{tabular}{|l|lllc|}
\hline Atom & \multicolumn{1}{|c}{$\mathbf{X}$} & \multicolumn{1}{c}{$\mathbf{y}$} & \multicolumn{1}{c}{$\mathbf{z}$} & $\mathbf{U}_{\text {eq }}\left(\AA^{\mathbf{2}} \mathbf{x} \mathbf{1 0}^{-3}\right)$ \\
\hline $\mathbf{P b}(\mathbf{1})$ & $1 / 3$ & $2 / 3$ & $0.00786(5)$ & $9.0(1)$ \\
$\mathbf{P b}(\mathbf{2})$ & $0.25542(3)$ & $0.01425(3)$ & 0.25 & $10.1(1)$ \\
$\mathbf{V}$ & $0.4097(2)$ & $0.3836(1)$ & 0.25 & $5.4(3)$ \\
$\mathbf{C l}$ & 0 & 0 & 0 & $10.0(6)$ \\
$\mathbf{O ( 1 )}$ & $0.3329(8)$ & $0.4973(8)$ & 0.25 & $13(1)$ \\
$\mathbf{O ( 2 )}$ & $0.6039(7)$ & $0.4857(7)$ & 0.25 & $14(1)$ \\
$\mathbf{O ( 3 )}$ & $0.3587(6)$ & $0.2689(6)$ & $0.0644(6)$ & $17.0(9)$ \\
\hline
\end{tabular}

$U_{\text {eq }}$ is defined as one third of the trace of the orthogonalized $U_{\mathrm{ij}}$ tensor
Table 3 Anisotropic displacement parameters $U_{\mathrm{ij}}\left(\AA^{2} \times 10^{-3}\right)$ for vanadinite from Mibladén, Morocco.

\begin{tabular}{|l|cccccc|}
\hline Atom & $\mathbf{U}_{\mathbf{1 1}}$ & $\mathbf{U}_{\mathbf{2 2}}$ & $\mathbf{U}_{\mathbf{3 3}}$ & $\mathbf{U}_{\mathbf{1 2}}$ & $\mathbf{U}_{\mathbf{1 3}}$ & $\mathbf{U}_{\mathbf{2 3}}$ \\
\hline $\mathbf{P b}(\mathbf{1})$ & $10.7(1)$ & $10.7(1)$ & $5.5(2)$ & $5.38(7)$ & 0 & 0 \\
$\mathbf{P b}(\mathbf{2})$ & $8.1(2)$ & $6.3(2)$ & $14.6(2)$ & $2.5(1)$ & 0 & 0 \\
$\mathbf{V}$ & $6.4(5)$ & $5.1(5)$ & $5.1(5)$ & $3.3(5)$ & 0 & 0 \\
$\mathbf{C l}$ & $11.2(9)$ & $11.2(9)$ & $7.5(9)$ & $5.6(4)$ & 0 & 0 \\
$\mathbf{O ( 1 )}$ & $21(3)$ & $20(3)$ & $10(3)$ & $17(3)$ & 0 & 0 \\
$\mathbf{O ( 2 )}$ & $10(3)$ & $13(3)$ & $19(3)$ & $4(2)$ & 0 & 0 \\
$\mathbf{O ( 3 )}$ & $23(2)$ & $20(2)$ & $15(2)$ & $16(2)$ & $10(2)$ & $9(2)$ \\
\hline
\end{tabular}

Table 4 Comparison between two different crystal-structure refinement approaches of vanadinite and results obtained by Dai - Hughes (1989).

\begin{tabular}{|c|c|c|c|c|c|c|c|}
\hline \multirow[b]{2}{*}{ Atom } & \multirow[b]{2}{*}{$\mathrm{CN}$} & \multicolumn{2}{|c|}{$\begin{array}{l}\text { This study - full } \\
\text { anisotropic refinement }\end{array}$} & \multicolumn{2}{|c|}{$\begin{array}{l}\text { This study - oxygen } \\
\text { atoms refined isotropically }\end{array}$} & \multicolumn{2}{|c|}{ Dai - Hughes (1989) } \\
\hline & & $\mathrm{ECoN}$ & BVS & ECoN & BVS & ECoN & BVS \\
\hline $\mathrm{Pb}(1)$ & 9 & 6.97 & 1.98 & 6.95 & 1.98 & 6.88 & 1.91 \\
\hline $\mathrm{Pb}(2)$ & 8 & 4.46 & 2.04 & 4.44 & 2.03 & 4.46 & 1.96 \\
\hline V & 4 & 3.99 & 5.14 & 3.99 & 5.15 & 3.99 & 5.27 \\
\hline $\mathrm{Cl}$ & & & 1.14 & & 1.14 & & 1.10 \\
\hline $\mathrm{O}(1)$ & & & 2.08 & & 2.07 & & 2.07 \\
\hline $\mathrm{O}(2)$ & & & 2.15 & & 2.16 & & 2.23 \\
\hline $\mathrm{O}(3)$ & & & 1.94 & & 1.95 & & 1.91 \\
\hline
\end{tabular}

Notes: $\mathrm{CN}$ = coordination number; ECoN = effective coordination number of Hoppe (1979) calculated using the program of Rieder (1993); BVS = bond valence sum calculated by program IVTON (Balić-Žunić - Vicković 1996) using default program settings. 
Table 5 Selected bond lengths $(\AA)$ and distortion parameters for two different crystal-structure refinement approaches of vanadinite, compared with those obtained by Hughes - Dai (1989).

\begin{tabular}{|l|ccc|}
\hline & $\begin{array}{c}\text { This study-full } \\
\text { anisotropic } \\
\text { refinement }\end{array}$ & $\begin{array}{c}\text { This study-oxygen } \\
\text { atoms refined } \\
\text { isotropically }\end{array}$ & $\mathbf{( 1 9 8 9 )}$ \\
\hline V-O3 & $1.701(5)$ & $1.699(5)$ & $1.70(1)$ \\
V-O3 & $1.701(5)$ & $1.699(5)$ & $1.70(1)$ \\
V-O1 & $1.709(10)$ & $1.708(10)$ & $1.70(2)$ \\
V-O2 & $1.732(7)$ & $1.730(7)$ & $1.69(1)$ \\
Mean & 1.711 & 1.709 & 1.69 \\
& & $2.483(6)$ & $2.49(1)$ \\
Pb1-O1 & $2.483(6)$ & $2.483(4)$ & $2.49(1)$ \\
Pb1-O1 & $2.483(4)$ & $2.483(6)$ & $2.49(1)$ \\
Pb1-O1 & $2.484(6)$ & $2.730(5)$ & $2.76(1)$ \\
Pb1-O2 & $2.728(5)$ & $2.730(4)$ & $2.76(1)$ \\
Pb1-O2 & $2.728(7)$ & $2.730(7)$ & $2.76(1)$ \\
Pb1-O2 & $2.728(7)$ & $2.943(7)$ & $2.95(1)$ \\
Pb1-O3 & $2.943(7)$ & $2.944(4)$ & $2.95(1)$ \\
Pb1-O3 & $2.944(4)$ & $2.944(6)$ & $2.95(1)$ \\
Pb1-O3 & $2.944(6)$ & 2.719 & 2.73 \\
Mean & 2.718 & & \\
& & $2.324(6)$ & $2.34(1)$ \\
Pb2-O2 & $2.325(6)$ & $2.570(5)$ & $2.58(1)$ \\
Pb2-O3 & $2.569(5)$ & $2.570(5)$ & $2.68(1)$ \\
Pb2-O3 & $2.569(5)$ & $2.655(7)$ & $2.68(1)$ \\
Pb2-O3 & $2.656(7)$ & $3.1454(6)$ & $3.1569(7)$ \\
Pb2-Cl & $3.1454(6)$ & $3.1454(6)$ & $3.1569(7)$ \\
Pb2-Cl & $3.1454(6)$ & $3.209(9)$ & $3.20(1)$ \\
Pb2-O1 & $3.210(9)$ & 2.803 & 2.83 \\
Mean & 2.803 & 12.49 & 11.82 \\
BAV* & 12.39 & 0.61 & 0.25 \\
BLD** & 0.62 & & \\
\hline & & & \\
\hline
\end{tabular}

*BAV - bond angle variance (Robinson et al. 1971)

**BLD - bond length distortions (Renner - Lehmann 1986)

was introduced by Renner - Lehmann (1986) and is defined as: $\mathrm{BLD}=100 / \mathrm{n} \sum_{\mathrm{i}=1}^{\mathrm{n}}\left|\left((\mathrm{T}-\mathrm{X})_{\mathrm{i}}-(\mathrm{T}-\mathrm{X})_{\mathrm{m}}\right) /(\mathrm{T}-\mathrm{X})_{\mathrm{m}}\right|$ where $\mathrm{m}=$ average and $\mathrm{i}$ is the number of bonds. These distortion parameters were calculated from our refinements and the data of Dai - Hughes (1989) and are summarized in Table 5. Since the distortion parameters are relative, a straightforward comparison among them is possible. Finally, compared to the data of Dai - Hughes (1989), we encountered a larger bond length distortion for the $\mathrm{VO}_{4}$ tetrahedron in our full anisotropic refinement.

Vanadinite, mimetite and pyromorphite form an isomorphic series. The major difference is the central atom in the $\mathrm{XO}_{4}$ tetrahedra, which is alternatively $\mathrm{V}^{+5}$ in vanadinite, $\mathrm{As}^{+5}$ in mimetite and $\mathrm{P}^{+5}$ in pyromorphite. Vanadium is the largest central atom among the minerals belonging to the pyromorphite series. As a consequence, it might be interesting to compare the role of ionic radii of phosphorus (radius $0.38 \AA$ ), arsenic $(0.46 \AA)$ and vanadium $(0.54 \AA)$ on the distortion parameters of tetrahedra in apatite-type structure of these minerals. To calculate the parameters, we used published structural data from the Inorganic Crystal Structure Database database (Fachinformationszentrum Karlsruhe 2003) for pyromorphite (ICSD \#50587) and mimetite (ICSD \#69960).

The bond length distortion increases with the decreasing size of the central ion. The smaller tetrahedra in pyromorphite appear to be more distorted $(\mathrm{BLD}=1.26)$ than those in mimetite $(\mathrm{BLD}=1.18)$. The tetrahedra in vanadinite display the lowest BLD (0.62). The opposite holds for bond angle variance; BAV values for pyromorphite, mimetite and vanadinite are 5.5, 7.38, 12.39, respectively. This behaviour is in accordance with the principle described by Renner - Lehmann (1986) and Lager - Gibbs (1973). If the forces acting upon the central ion outside a certain coordination unit are negligible, the central ion tends to stay in the centre of the coordination unit. This principle requires that the ratio between bond length distortion and angle variance is always negative, i.e. elongation of a particular bond tends to decrease the bond adjacent to it and vice versa (Lager - Gibbs 1973). As shown in Table 5 our refinement provided values that match this trend better than the values calculated from data of Dai - Hughes (1989).

\section{Conclusions}

The presence of atoms with high atomic numbers does not preclude the refinement of anisotropic displacement parameters for oxygen atoms in vanadinite. Refinement of anisotropic displacement parameters, however, was found to have little effect on the crystal structure. This is demonstrated in Table 4 where effective coordination numbers and bond-valence sums are compared for two refinement approaches. In the first one, all the atoms were refined anisotropically. In the second one, heavy atoms were refined anisotropically and oxygen atoms isotropically. Moreover, these results are further compared to the data of Dai - Hughes (1989) which were refined following the second scheme used in this paper. The refinement carried out by Dai - Hughes (1989) resulted in a less deformed $\mathrm{VO}_{4}$ tetrahedron. The refinement presented here provided higher values for BAV and BLD for vanadium, which agrees better with the values typical for structures containing a $\mathrm{VO}_{4}$ tetrahedron.

Acknowledgements. This work was supported by the internal project of Czech Geological Survey (project number 3230), and falls within the research plan AV0 Z30130516 of the Institute of Geology AS CR. We thank M. Rieder and J. Cempírek for their valuable comments on the manuscript.

Submitted October 30, 2006 


\section{References}

Altomare, A. - Cascarano, G. - Giacovazzo, C. - Guagliardi, A. - Burla, M. C. - Polidori, G. - Camalli, M. (1994): SIR-92 - a program for automatic solution of crystal structures by direct methods. - J. Appl. Cryst., 27: 435.

Balić-Žunić, T. - Vicković, I. (1994): IVTON. a program for the calculation of geometrical aspects of crystal structures and some crystal chemical applications. - Geological Institute, Univ of Copenhagen, Denmark.

Brese, N. E. - O'Keefe, M. (1991): Bond-valence parameters for solids. Acta Cryst., B41:192-197.

Crystal Impact (2004): DIAMOND 3.0. - visual crystal structure information system. - Crystal Impact, Bonn, Germany.

Dai, Y. - Hughes, J. M. (1989): Crystal-structure refinements of vanadinite and pyromorphite. - Can. Mineral., 27: 189-192.

Farrugia, L. J. (1999): WinGX suite for small molecule single-crystal crystallography. - J. Appl. Cryst., 32: 837-838.

Fachinformationszentrum Karlsruhe (2003): Inorganic Crystal Structure Database, version 1.2.1.

Félenc, R. - Lenoble, J. P. (1965): Le gîte de Plomb de Mibladen. - Notes Mem. Serv. Géol. Maroc. 181:185-204.

Hendricks, S. B.-Jefferson, M. E. - Mosley, V. M. (1932): The crystal structures of some natural and synthetic apatite-like substances. $-\mathrm{Z}$. Kristallogr., 81: 352-369.

Hoppe, R. (1979): Effective coordination numbers (ECoN) and mean fictive ionic radii (MEFIR). - Z. Kristallogr., 150: 23-52.

Jébrak, M. - Marcoux, É. - Nasloubi, M. - Zaharaoui, M. (1998): From sandstone- to carbonate-hosted stratabound deposits: an isotope study of galena in the Upper-Moulouya District (Morocco). - Mineral. Dep., 33: 406-415.

Lager, G. A. - Gibbs, G. V. (1973): Effect of variations in $\mathrm{O}-\mathrm{P}-\mathrm{O}$ and $\mathrm{P}-\mathrm{O}-\mathrm{P}$ angles on $\mathrm{P}-\mathrm{O}$ bond overlap populations for some selected ortho- and pyrophosphates. - Am. Mineral., 58: 756-764.

Mandarino, J. A. - Back, M. E. (2004): Fleischer's Glossary of Mineral species 2004. The Mineralogical record Inc., Tuscon, 309 pp.

Nonius (1997-2000): COLLECT. Nonius BV, Delft, The Netherlands.

Otwinowski, Z. - Minor, W. (1997): Processing of X-ray diffraction data collected in oscillation mode. - Methods. Enzymol., 276: 307326.

Rieder, M. (1993): Program HOPPE for calculation of MEFIR, ECoN and mean from FIRs. Faculty of Science, Charles University, Prague, Czech Republic.

Renner, B. - Lehmann, G. (1986): Correlation of angular and bond length distortions in TO4 units in crystals. - Z. Kristallogr., 175: 43-59.

Robinson, K. - Gibbs, G. V. - Ribbe, P. H. (1971): Quadratic elongation: A quantitative measure of distortion in coordination polyhedra. Science, 172: 567-570.

Sheldrick, G. M. (1997): SHELX97. Programs for Crystal Structure Analysis. Release 97-2. Institut für Anorganische Chemie, Universität Göttingen, Germany.

Spek, A. L. (2001): PLATON. A Multipurpose Crystallographic Tool. Utrecht University, The Netherlands.

Trotter, N. - Barnes, W. H. (1958): The structure of vanadinite. - Can. Miner., 6: 161-173.

White, J. S. (1984): Vanadinite from Toussit, Morocco, and comments on endlichite. - Mineral. Rec, 15: 347-350.

\section{Krystalová struktura vanadinitu: zpřesnění anizotropních teplotních parametrů}

Krystalová struktura minerálu vanadinitu, $\mathrm{Pb}_{5}\left(\mathrm{VO}_{4}\right)_{3} \mathrm{Cl}, \mathrm{z}$ lokality Mibladén, Maroko, byla zpřesněna z monokrystalových rtg difrakčních dat. Plně anizotropní zpřesnění krystalové struktury bylo provedeno v hexagonální prostorové grupě $P 6_{3} / m$, mřížkové parametry $a=10.2990(2), c=7.3080(1) \AA$, $V=671.30(2) \AA^{3} Z=2, s R$ faktorem 0.0197 . Odchylky bond valencí od ideálních hodnot pro kationty jsou v prŕípadě plně anizotropního zpřesnění struktury menší než při zpřesněním izotropním. 